\title{
Creating Educational Trifold Brochures from Microsoft Word® Templates: An Example from the Florida Master Naturalist Program ${ }^{1}$
}

Martin B. Main and Ginger M. Allen²

\section{Introduction}

Brochures are inexpensive and effective tools for providing information. Trifold brochures are constructed by folding an $81 / 2$-by-11" sheet of paper twice to create three panels on each side, each of which can highlight different messages. Trifold brochures have the added advantage that their convenient size can fit in a standard \#10 envelope.

This document provides tips and guidelines for developing a trifold brochure and includes a Microsoft Word ${ }^{\circledR}$ template that can be copied and easily modified to present the reader a message. Additional information on how to insert images and modify text and style, as well as other tips that will assist with the mechanics of producing an educational brochure, are provided within the body of the template. Although this document and the associated template provided were created to facilitate the development of educational trifold brochures by students of the UF/IFAS Florida Master Naturalist Program (www.MasterNaturalist.org), the instructions provided can easily be modified to present other types of information.

\section{Developing Your Brochure Theme}

A brochure should have a target audience and an educational objective, which might also be described as the message or theme. In some cases, the target audience may be very general, such as a group of visitors to a nature center. In these cases, the theme may be tailored to appeal to a broader audience. If the target audience is very specific, such as fishermen at boat landings, the theme should target that audience. So, when developing your theme, ask, "who will be getting this brochure and why"?

The brochure theme provides the structure for the body of information and the take-home message for your audience. A hodgepodge of information that doesn't clearly contribute to a theme is unlikely to be useful in communicating a message to the reader. For example, a theme may be the description of a program or facility, conservation of a resource, boating guidelines in seagrass meadows, or

1. This document is Fact Sheet WEC 204, one of a series of the Wildlife Ecology and Conservation Department, Florida Cooperative Extension Service, Institute of Food and Agricultural Sciences, University of Florida. Original publication date July 2006. Visit the EDIS Web Site at http://edis.ifas.ufl.edu.

2. Martin B. Main, associate professor and wildlife extension specialist, and Ginger M. Allen, senior biologist, Department of Wildlife and Conservation, Institute of Food and Agricultural Sciences, University of Florida, Gainesville, FL 32611-0304.

The use of trade names in this publication is solely for the purpose of providing specific information. UF/IFAS does not guarantee or warranty the products named, and references to them in this publication does not signify our approval to the exclusion of other products of suitable composition.

The Institute of Food and Agricultural Sciences (IFAS) is an Equal Opportunity Institution authorized to provide research, educational information and other services only to individuals and institutions that function with non-discrimination with respect to race, creed, color, religion, age, disability, sex, sexual orientation, marital status, national origin, political opinions or affiliations. U.S. Department of Agriculture, Cooperative Extension Service, University of Florida, IFAS, Florida A. \& M. University Cooperative Extension Program, and Boards of County Commissioners Cooperating. Larry Arrington, Dean 
information about the ecology of a local ecosystem or a particular plant or animal, to list a few.

Developing the theme may require narrowing your topic, which will help you focus and prioritize information for the limited space available. A simple three-step approach used to narrow and define themes for interpretive programs can be useful in developing themes for informational brochures as well:

1. Select a broad topic (example: seagrass meadows).

2. Narrow your topic (example: why fishermen should be concerned about damage to seagrass meadows from boat propellers).

3. Write a theme statement as a complete sentence (example: "Seagrass meadows are the nurseries of the ocean and are critical to Florida's fisheries. Protect them from your boat propeller.").

In developing the body of information within the brochure, it is important to ask yourself whether that information addresses your theme and provides a clear take-home message that the reader will understand.

\section{Tips for Designing Your Brochure}

A couple of key tips can make your brochure more attractive, readable, and effective in conveying your message. In particular, it is important to use the different panels of the trifold brochure in the most effective manner. Professional brochure designers recommend using the different panels of a trifold brochure to provide different parts of your educational message.

- Front panel. The front cover should be visually appealing and provide enough content to invite the reader to open the piece and read more. This may simply include a logo or image and title that describe the theme of the brochure. Avoid too much clutter on the front panel.

- Back panel. In most cases, the back panel should be limited to credits and additional contact information. It is also a good spot for a testimonial. This is the panel people are least likely to read, so avoid putting key messages on the back panel.
- Inside front panel. This is considered to be the most important panel in the brochure because it is the information that will immediately be seen when the brochure is opened. This panel should provide a statement or testimonial that summarizes your message. Brochure designers recommend that you design this panel last, although it is the first panel seen by the reader. By writing the inside spread first, you will have a better idea of what you want to summarize on the inside front panel. This is also a good place to include your Web site or other direct contact information.

- Inside three-panel spread. This is the body of the brochure. When you open the trifold brochure fully, you have three full panels to develop your theme and accomplish your educational objective.

Additional points to consider when designing your brochure include making the brochure visually appealing and inviting to read. Avoid a cluttered appearance. Use space to create an open look, and develop your message so it is clear and concise. Use only high-quality photographs or images (at least 300 dpi), and be clear on permissions and credits on borrowed material and on the use of established logos. For example, Florida Master Naturalist Program students developing final projects should use the official Florida Master Naturalist Program logo provided on the brochure template.

Regardless of how attractive your brochure is, it will only be as good as the information it provides. Ensure that information provided in the brochure is factual and understandable. Avoid technical jargon and other forms of communication that alienate readers or obscure your message. Avoid being long-winded; succinct and concise writing is a good rule to follow.

\section{Using the Trifold Brochure Template}

The Microsoft Word ${ }^{\circledR}$ trifold brochure template (brochure_template) associated with this document can be customized to provide your educational message. The brochure template provides additional hints, procedures, and details that will assist you in 
changing background color, inserting images and graphics, and choosing text size and style to create a personalized trifold brochure. Save the brochure file on your personal computer often as you progress and again when you finish.

It is advisable to convert the completed brochure from a Word® document to a Portable Document Format (PDF) file prior to mass printing. PDF writer software is needed to make this conversion and can be purchased (or you can search for "free PDF writer" on the Internet and download a software program). Viewing and printing a PDF file requires Adobe ${ }^{\circledR}$ Acrobat Reader, which is built into most browsers and can be downloaded free from Adobe ${ }^{\circledR}$. When printing the brochure, choose standard size, 8 1/2-by-11" paper and set the orientation to landscape (under page setup).

\section{Additional Sources of Information}

Ballantyne, Roy. 2002. Spreading the Word: Designing Brochures, Queensland University of Technology, available online at: http://www.interpretivesigns.qut.edu.au/ brochures.html.

Egelhoff, Tom. 1999. How To Design \& Write a Basic Brochure, available online at: http://www.smalltownmarketing.com/ brochuredesign.html.

Main, Martin B. and Ginger M. Allen. 2002. Florida Master Naturalist Program, Fact Sheet WEC \#161, available online at: http://edis.ifas.ufl.edu/UW172.

Prizzia, Anna M., Mark E. Hostetler, and Martin B. Main. 2004. Developing Sign Displays for Conveying Information, Fact Sheet WEC \#180, available online at: http://edis.ifas.ufl.edu/UW196.

Professional Advertising. 2004. Effective Brochure Design: How To Create Brochures That Get Action, available online at: http://www.myprofessionaladvertising.com.

Speedcolor. 2003. Tips on Effective Design and Type Settings, available online at: http://www.speedcolor.com/designtips.asp.
Szala, Joseph. 2004. Brochures That Pitch and Don't Get Pitched, available online at: http://www.webuneek.com/ modules.php?op=modload $\&$ name $=$ News $\&$ file $=$ article $\&$ sid $=19 \&$ mode $=$ thread $\&$ order $=0 \&$ thold $=0 \&$ POSTN UKESID=06970d911c03f70c78af068f8d39f2dd. 